Vol.5 No.1

\title{
FAKTOR-FAKTOR YANG MEMPENGARUHI KETERTARIKAN PADA ORGANISASI DAN INTENSI UNTUK MENDAPATKAN PEKERJAAN: JENIS KELAMIN SEBAGAI VARIABEL MODERASI
}

\author{
Nayunda Andhika Sari
}

Universitas Indonesia

\section{A R T IC LE INFO}

\begin{abstract}
Keywords : an interest in the Organization, the intensi to get the job opportunities, wages, promotion, LAYOFF policy, environmental policy.
\end{abstract}

Kata Kunci : : ketertarikan pada organisasi, intensi untuk mendapatkan pekerjaan, upah, kesempatan promosi, kebijakan PHK, kebijakan lingkungan.

Corresponding author :

Nayunda Andhika Sari

nayunda.as10@gmail.com

\begin{abstract}
Abstrack : This research aims to know the influence of promotional opportunities, wages, layoffs, policy and environmental policy towards an interest in the Organization and intensi to get the job. The study also wants to prove that the conditions under which prospective employees with potential to feel interested in the Organization and the conditions under which the potential prospective employees have a desire to work in an organization are two different things. Based on the results of the study, factors that influence different organizations with an interest in the factors that affect intensi to get a job. With the final level of student respondents and methods data collection policy-capturing, research results show that environmental policy owned organization is the strongest factors that can predict potential employee candidate attraction against these organizations, while the level of the wages offered the Organization became the most powerful factor in affecting the desire to get a job in an organization.
\end{abstract}

Abstrak : Penelitian ini bertujuan mengetahui pengaruh upah, kesempatan promosi, kebijakan PHK, dan kebijakan lingkungan terhadap ketertarikan pada organisasi dan intensi untuk mendapatkan pekerjaan. Penelitian ini juga ingin membuktikan bahwa kondisi dimana calon karyawan potensial merasa tertarik pada organisasi dan kondisi dimana calon karyawan potensial memiliki keinginan untuk bekerja di suatu organisasi merupakan dua hal yang berbeda. Berdasarkan hasil penelitian, faktor yang mempengaruhi ketertarikan pada organisasi berbeda dengan faktor yang mempengaruhi intensi untuk mendapatkan pekerjaan. Dengan responden mahasiswa tingkat akhir dan metode pengumpulan data policy-capturing, hasil penelitian menunjukkan bahwa kebijakan lingkungan yang dimiliki organisasi merupakan faktor terkuat yang dapat memprediksi ketertarikan calon karyawan potensial terhadap organisasi tersebut, sedangkan tingkat upah yang ditawarkan organisasi menjadi faktor yang paling kuat dalam mempengaruhi keinginan untuk mendapatkan pekerjaan di suatu organisasi. 


\section{Latar Belakang}

\section{PENDAHULUAN}

Pada era persaingan intelektual (intelligence competitiveness) saat ini, organisasi membutuhkan orangorang terbaik dengan keahlian terbaik pula agar tetap bisa menghadapi persaingan yang semakin ketat. Hal ini sangat berkaitan dengan konsep rekruitmen, dimana prosesnya mempengaruhi hasil yang diterima oleh organisasi tersebut. Artinya, jika proses rekruitmen berjalan efektif, maka karyawan yang didapatkan organisasi pun akan tepat sasaran. Untuk itu, organisasi perlu terlebih dahulu mengerti seberapa jauh dampak yang ditimbulkan oleh proses rekruitmen terhadap hasil yang diinginkan organisasi.

Bergerak dari pandangan bahwa organisasi sebagai tempat yang diinginkan untuk bekerja (Rynes, 1991), Aiman-Smith, Bauer, dan Cable (2001) memaknai ketertarikan pada organisasi sebagai suatu sikap atau ekspresi positif pada organisasi, yang memandang organisasi sebagai suatu kesatuan yang diinginkan untuk menjalin hubungan. Hal ini dilandasi oleh penelitian Barber (1998), yang menyatakan fase awal dari rekruitmen merupakan tahap dimana organisasi mencoba untuk mengembangkan jumlah calon karyawan potensial atau tahap dimana individu menilai keinginannya pada hubungan potensial dengan organisasi. Sehingga, konsep ketertarikan pada organisasi terbatas pada respon positif secara pasif terhadap organisasi tersebut melalui proses rekruitmennya.

Berbeda dengan konsep sebelumnya, intensi untuk mendapatkan pekerjaan dianggap respon yang lebih aktif terhadap organisasi. Aiman-Smith, Bauer, dan Cable (2001) memandang variabel dependen ini sebagai keinginan mengambil tindakan untuk mencari tahu informasi mengenai organisasi, berhubungan dengan organisasi, dan mencoba mengikuti wawancara dengan organisasi tersebut. Hal ini juga sesuai dengan fase kedua Barber yaitu pencarian berkelanjutan (intensive search), dimana calon karyawan potensial terlibat secara aktif dalam pencarian kemungkinan tersedianya pekerjaan di suatu organisasi.

Bersumber pada penelitian Aiman-Smith, Bauer, dan Cable (2001), penelitian ini mengintegrasikan penelitian-penelitian sebelumnya mengenai citra perusahaan dan karakteristik pekerjaan. Termasuk di dalam penelitian ini, peneliti meneliti pengaruh relatif secara menyeluruh dari upah, kesempatan promosi, kebijakan PHK, dan kebijakan lingkungan pada ketertarikan calon karyawan potensial pada organisasi dan intensi mereka untuk mendapatkan pekerjaan di organisasi tersebut. Pada akhirnya, peneliti ingin mengidentifikasi perbedaan konsep ketertarikan pada organisasi dengan intensi untuk mendapatkan pekerjaan dengan mengetahui perbedaan faktorfaktor yang paling mempengaruhi keduanya

\section{TINJAUAN PUSTAKA}

\section{Ketertarikan pada Organisasi (Organizational Attractiveness)}

Ketertarikan pada organisasi merupakan sikap yang memandang organisasi sebagai tempat yang diinginkan untuk bekerja (Rynes, 1991). Dilandaskan pada teori itu, Aiman-Smith, Bauer, dan Cable (2001) memaknai ketertarikan pada organisasi sebagai suatu sikap atau ekspresi positif pada organisasi, yang memandang organisasi sebagai suatu kesatuan yang diinginkan untuk menjalin hubungan. Hal ini dilandasi pula oleh penelitian Barber (1998) yang menyatakan fase awal dari rekruitmen merupakan tahap dimana organisasi mencoba untuk mengembangkan jumlah calon karyawan potensial atau tahap dimana individu menilai keinginannya pada hubungan potensial dengan organisasi. Dengan demikian, definisi ketertarikan pada organisasi terbatas pada respon positif secara pasif terhadap organisasi tersebut melalui tahapan awal proses rekruitmennya.

Menurut Aiman-Smith, Bauer, dan Cable (2001), beberapa komponen faktor organisasi yang dapat mempengaruhi ketertarikan pada organisasi, antara lain pengelolaan organisasi yang baik, praktek tenaga kerja yang baik, dukungan terhadap kegiatan kebudayaan, kebijakan pro-lingkungan, dan lain-lain. Pfeffer (1998) mengidentifikasi keamanan pekerjaan sebagai kebijakan organisasi yang terbaik untuk menarik dan mempertahankan karyawannya. Judge dan Bretz (1992) berpendapat bahwa para pencari kerja mempersepsikan nilai organisasi dipengaruhi oleh kebijakan perlindungan lingkungan yang dimiliki organisasi tersebut. Selain itu, organisasi dapat mempublikasikan kegiatan sosialnya untuk menjaga citra organisasi yang akan meningkatkan ketertarikan calon karyawan potensial (Aiman-Smith, Bauer, \& Cable, 2001).

Beberapa penelitian juga mengidentifikasi ketertarikan calon karyawan potensial di tahapan awal rekruitmen, dimana ketertarikan tersebut dipengaruhi oleh persepsi calon karyawan potensial akan karakterisitik pekerjaan dan karakteristik organisasi, seperti upah, kesempatan promosi, lokasi, alur karir, dan struktur organisasi 
(Cable \& Graham, 2000; Highhouse et al., 1999; Lievens, Decaesteker, Coetsier, \& Geirnaert, 2001; Lievens \& Highhouse, 2003; Turban \& Keon, 1993). Berkaitan dengan rekuimen, kesadaran akan eksistensi organisasi juga dapat mempengaruhi ketertarikan calon karyawan potensial pada organisasi di awal rekruitmen. Semakin popular organisasi tersebut, maka akan semakin menarik (Cable \& Graham, 2000; Gatewood, Gowan, \& Lautenschlager, 1993; Turban, 2001; Turban \& Greening, 1997; Brooks, M.E., Highhouse, Russell, \& Mohr, 2003).

\section{Intensi untuk Mencari Pekerjaan (Job Pursuit Intention)}

Berbeda dengan konsep ketertarikan pada organisasi yang lebih cenderung terbatas pada respon positif yang ditunjukkan secara pasif kepada organisasi, intensi untuk mendapatkan pekerjaan ditunjukkan dengan sikap yang lebih proaktif. Intensi untuk mendapatkan pekerjaan didefinisikan oleh Aiman-Smith, Bauer, dan Cable (2001) sebagai keinginan mengambil tindakan untuk mencari tahu informasi mengenai organisasi, berhubungan dengan organisasi, dan mencoba mengikuti wawancara dengan organisasi tersebut. Untuk konsep ini, tahapan awal rekruitmen tidak lagi representatif, karena calon karyawan potensial sudah bergerak lebih jauh yang sesuai dengan fase rekruitmen Barber selanjutnya, yaitu pencarian berkelanjutan (intensive search). Pada tahap ini, calon karyawan potensial terlibat secara aktif dalam pencarian kemungkinan tersedianya pekerjaan di suatu organisasi.

Sebagaimana penjelasan sebelumnya, banyak hasil penelitian yang menunjukkan bahwa faktor-faktor yang mempengaruhi intensi untuk mendapatkan pekerjaan berbeda dengan faktor-faktor dari ketertarikan pada organisasi. Banyak faktor yang dapat mempengaruhi intensi untuk mendapatkan pekerjaan. Penelitian sebelumnya mengenai rekruitmen dan pencarian pekerjaan mengidentifikasi faktor upah, kesempatan promosi, lokasi, benefit, otonomi, fleksibilitas, dan tipe pekerjaan (Cable \& Judge, 1994; Rynes, 1991; Rynes et al., 1983; Schwab, Rynes, \& Aldag, 1987). Metode policy-capturing banyak digunakan peneliti untuk menganalisis pengaruh dari variabel independen terhadap pencarian dan pemilihan pekerjaan. Sebagai contoh, Feldman dan Arnold (1978) berpendapat bahwa upah dan benefit memiliki pengaruh yang paling besar terhadap pemilihan pekerjaan dibandingkan faktor kesempatan menggunakan keahlian dan kemampuan, otonomi dan kemandirian, tanggung jawab, penyediaan produk dan jasa yang diperlukan, dan fleksibilitas waktu kerja. Penelitian mengenai keputusan pemilihan pekerjaan menemukan bahwa individu mempertimbangkan keamanan pekerjaan, kesempatan promosi, dan karakterisitik organisasi sebagai faktor yang penting, namun upah tetap merupakan faktor yang paling menentukan (Jurgensen, 1978).

\section{Upah (Payment)}

Konsep upah yang digunakan pada penelitian ini disesuai dengan variabel upah yang digunakan dalam penelitian Aiman-Smith, Bauer, dan Cable (2001), yaitu tingkat upah awal dari suatu pekerjaan yang ditawarkan kepada calon karyawan potensial yang baru lulus dari universitas tertentu dengan latar pendidikan S1. Penggunaan upah sebagai salah satu variabel independen dalam penelitian ini dilandasakan pada hasil penelitian-penelitian sebelumnya. Penelitian ini menggunakan upah yang merupakan komponen dari total kompensasi sebagai variabel juga didukung oleh penelitian Gomez-Mejia \& Balkin, 1992, yang menyatakan bahwa total sistem kompensasi terdiri dari berbagai dimensi, beberapa diantaranya lebih stratejik dan fokus pada pencapaian tujuan organisasi dibandingkan dimensi yang lain. Dalam penelitian Cable dan Judge (1994), mereka menggunakan upah sebagai salah satu dimensi upah untuk mengukur pengaruhnya pada keputusan pencarian pekerjaan. Ada beberapa atribut upah yang digunakan dalam penelitiannya, yaitu persaingan ekternal (upah), struktur upah internal (hirarki upah), kontribusi karyawan (kontribusi individual vs kontribusi kelompok), tunjangan (fleksibel $v s$ tetap), dan dasar pengupahan (berdasarkan pekerjaan $v s$ keahlian).

Hasil penelitian Aiman-Smith, Bauer, dan Cable (2001) juga menunjukkan pentingnya penggunaan upah sebagai salah satu variabel independen. Dari hasil penelitiannya, dapat diketahui bahwa faktor yang paling mempengaruhi intensi untuk mendapatkan pekerjaan adalah upah. Upah sebagai salah satu komponen dari total kompenasi, terbukti menjadi faktor terpenting yang menunjukkan bahwa dimensi kompensasi memiliki kekuatan yang sangat besar, yang menentukan apakah calon karyawan potensial memiliki intensi untuk mendapatkan pekerjaan pada suatu organisasi. Sedangkan untuk ketertarikan pada organisasi, upah menjadi faktor ke-tiga terkuat. Hasil penelitian ini pun sesuai dengan penelitian Feldman dan Arnold (1978) dan Rynes et al (1983) yang menyatakan bahwa upah dan kesempatan promosi dikatakan sebagai atribut yang paling konsisten dari faktor pekerjaan yang mempengaruhi intensi untuk 
mendapatkan pekerjaan.

\section{Kesempatan Promosi (Promotion Opportunity)}

Menurut Raymond A. Noe dalam bukunya yang berjudul "Employee Training and Development" (2005), definisi pengembangan karyawan adalah suatu komponen yang diperlukan dari usaha perusahaan untuk meningkatkan kualitas, untuk mempertahankan karyawan, untuk menghadapi tantangan persaingan global dan perubahan sosial, dan untuk memanfaatkan perkembangan teknologi dan perubahan dalam disain kerja. Organisasi melakukan banyak hal dalam mengembangkan kompetensi karyawannya, antara lain dengan pendidikan formal, penilaian potensi, pengalaman kerja, dan hubungan personal. Dan salah satu program yang digunakan organisasi untuk menambah pengalaman kerja karyawannya adalah dengan memberikan kesempatan promosi. Promosi diartikan sebagai suatu kemajuan ke posisi yang membutuhkan tanggung jawab, tantangan, dan otoritas yang lebih besar daripada pekerjaan sebelumnya. Dari definisi ini, dapat disimpulkan bahwa promosi ini bersifat naik ke tingkat yang lebih tinggi (upward).

Kesempatan promosi digunakan sebagai salah satu variabel independen dalam penelitian ini, dilandasakan pada hasil penelitian-penelitian sebelumnya, khususnya penelitian Aiman-Smith, Bauer, dan Cable (2001). Dari hasil penelitiannya dapat diketahui bahwa kesempatan promosi merupakan faktor ke-tiga terkuat yang mempengaruhi intensi untuk mendapatkan pekerjaan, dan faktor ke-empat terkuat yang mempengaruhi ketertarikan calon karyawan potensial pada organisasi. Penggunaan variabel ini pun didukung oleh penelitian Zedeck (1977) yang menemukan bahwa kesempatan promosi sebagai faktor yang paling penting, diikuti oleh upah, fleksibiltas, dan waktu penugasan.

\section{Kebijakan Pemutusan Hubungan Kerja (Lay-off Policy)}

Kebijakan PHK yang dilakukan oleh organisasi biasanya sebagai upaya untuk mengurangi tenaga kerja (downsizing). Pengurangan tenaga kerja adalah upaya sistematis yang dilakukan oleh perusahaan untuk mengurangi jumlah tenaga kerja dengan tujuan memperbaiki efisiensi dan kinerja. Upaya ini seringkali menimbulkan persepsi tidak adil bagi karyawan dan bisa berdampak buruk bagi organisasi. Kurangnya komitmen ini tidak hanya berdampak pada naiknya absensi dan menurunnya ketekunan, tapi juga menurunnya produktivitas. Inilah yang menyebabkan perusahaan gagal mencapai tujuan downsizing (Meyer et al., 1998; Lâmsâ \& Savolainen, 2000; Knudsen et al., 2003).

Definisi PHK yang digunakan dalam penelitian ini, dilandasi oleh ketentuan PHK berdasarkan UU No. 13 Tahun 2003 mengenai Ketenagakerjaan. PHK yang didefinisikan sebagai pengakhiran hubungan kerja karena suatu hal tertentu yang mengakibatkan berakhirnya hak dan kewajiban antara pekerja dan pengusaha. Kebijakan PHK digunakan sebagai salah satu variabel independen dalam penelitian ini, dilandasakan pada hasil penelitian-penelitian sebelumnya, khususnya penelitian Aiman-Smith, Bauer, dan Cable (2001). Dari hasil penelitiannya dapat diketahui bahwa kebijakan PHK merupakan faktor ke-dua terkuat yang mempengaruhi ketertarikan calon karyawan potensial pada organisasi dan intensi untuk mendapatkan pekerjaan.

\section{Kebijakan Lingkungan (Ecological Rating)}

Kebijakan lingkungan merupakan salah satu komponen dari tanggung jawab sosial. Tentunya, hal ini sangat berkaitan dengan hubungan organisasi dengan masyarakat, otomatis kebijakan lingkungan yang dilakukan organisasi akan dinilai baik atau buruknya oleh masyarakat. Kebijakan lingkungan dapat diterapkan pada aspek produk/jasa yang dihasilkan organisasi tersebut. Hal ini ditunjuukkan pada beberapa penelitian pemasaran yang menganalisis reaksi pelanggan pada produk yang bersahabat dengan lingkungan (green product) dan posisi kebijakan lingkungan organisasi tersebut di mata pelanggannya (Dowling, 1986; Gregory, 1991; Peattie \& Ratnayaka, 1992; Waski, 1992). Kebijakan lingkungan suatu organisasi dianggap penting paling tidak oleh beberapa segmen pelanggan dan berpengaruh langsung pada produk yang dihasilkan dan strategi pemasarannya (Brown \& Dacin, 1997; Carlson, Grove, \& Kangun, 1993; Ottman, 1992).

Ternyata, kebijakan lingkungan bukan hanya berdampak pada produknya, melainkan memegang peranan dalam bagaimana dan dimana investor menaruh investasinya. Sebagai contoh, beberapa investor memberikan investasinya hanya pada organisasi yang memenuhi persayaratan tingkat tanggung jawab sosialnya, dengan salah satu kriteria kebijakan lingkungan (Kinder, Lydenberg, \& Domini, 1992; Lowry, 1991; Miller, 1991). Dalam usaha 
untuk meng-“hijau"-kan bisnis-bisnis Amerika (Millstone \& Watts, 1992), penelitian membuktikan adanya dampak kebijakan lingkungan yang dilakukan organisasi kepada calon karyawan potensial.

Kebijakan lingkungan digunakan sebagai salah satu variabel independen dalam penelitian ini, dilandasakan pada hasil penelitian-penelitian sebelumnya, khususnya penelitian Aiman-Smith, Bauer, dan Cable (2001). Dari hasil penelitiannya dapat diketahui bahwa kebijakan lingkungan merupakan faktor yang paling mempengaruhi ketertarikan calon karyawan potensial pada organisasi. Hasil penelitian ini pun mendukung penelitian Judge dan Bretz (1992) yang menyatakan bahwa responden memberi peringkat tertinggi untuk dimensi lingkungan sebagai faktor yang mempengaruhi ketertarikan pada organisasi. Sedangkan untuk intensi untuk mendapatkan pekerjaan, kebijakan lingkungan menjadi faktor ke-empat terkuat.

Berdasarkan teori yang telah dibahas pada bab sebelumnya, ada beberapa hipotesis yang digunakan sebagai dasar dalam penelitian ini, antara lain:

H1 : Kebijakan lingkungan yang dimiliki organisasi merupakan faktor yang paling kuat dalam mempengaruhi ketertarikan pada organisasi.

H2 : Kebijakan PHK yang dimiliki organisasi merupakan faktor ke-dua yang paling kuat dalam mempengaruhi ketertarikan pada organisasi.

H3 : Tingkat upah yang ditawarkan organisasi merupakan faktor yang paling kuat dalam mempengaruhi intensi untuk mendapatkan pekerjaan.

H4 : Kesempatan promosi yang ditawarkan organisasi merupakan faktor ke-dua yang paling kuat dalam mempengaruhi intensi untuk mendapatkan pekerjaan

\section{Kerangka Konsep}

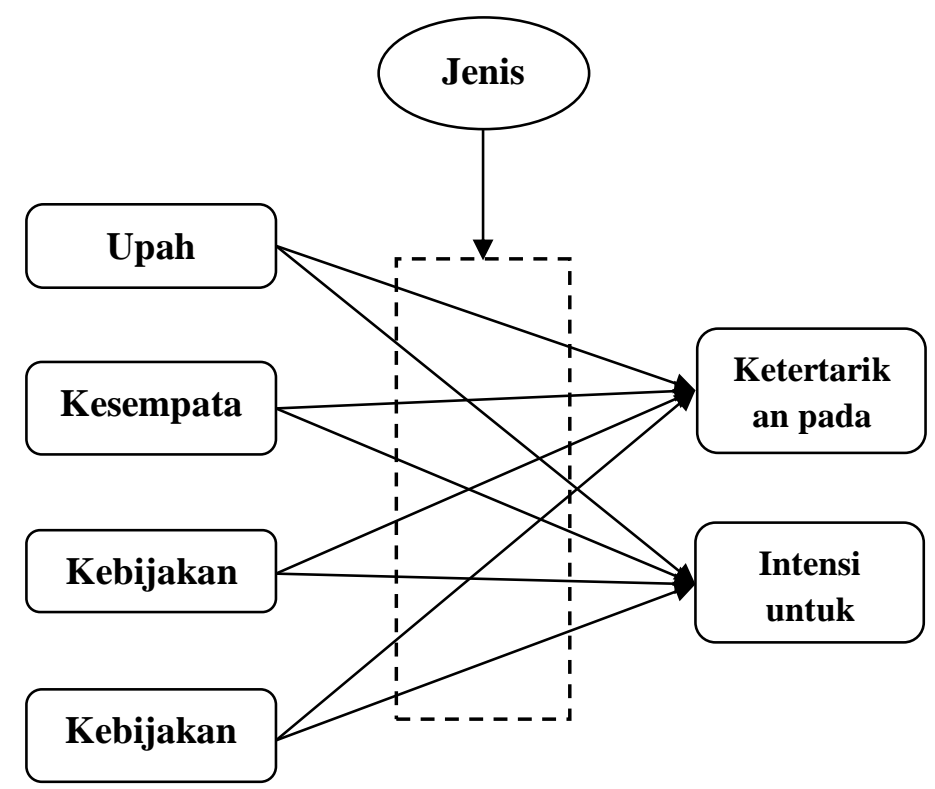

Gambar 1. Model Penelitian

METODE PENELITIAN

Penelitian ini menggunakan pendekatan policy-capturing. Policy-capturing adalah sebuah metode yang digunakan untuk menganalisa pertimbangan (judgement) yang didasari oleh berbagai stimuli yang multi dimensi dengan menggunakan metode model linear (Wiederman, 1999). Policy-capturing digunakan untuk menganalisa karakteristik personal dan organisasional yang mempengaruhi seleksi, alokasi balas jasa, atau hal lain dalam hubungan karyawan-perusahaan (Aiman-Smith, Scullen \& Barr, 2002). Metode ini digunakan untuk menganalisa pilihan pekerjaan oleh pencari kerja (Aiman-Smith, Bauer \& Cable, 2001; Williamson, Cope, Thompson \& 
Wuensch, 2002; Slaughter, Richard \& Martin, 2006), pengambilan keputusan dalam wawancara calon karyawan (Graves, \& Karren, 1992), penilaian kinerja (Hobson \& Gibson, 1983), dan penentuan alokasi kompensasi (Deshpande, \& Schoderbek, 1993; Zhou \& Martocchio, 2001; Hu, Hsu, Lee \& Chu, 2007) termasuk kepuasan terhadap kompensasi (Law \& Wong, 1998) serta keputusan kenaikan kompensasi (Barclay \& York, 2003).

\section{Metode Pengumpulan Data}

Metode policy-capturing yang digunakan pada penelitian ini menghasilkan pendekatan yang berbeda dalam penyusunan kuesioner dan pengukuran item-item untuk setiap variabel. Kuesioner menyajikan beberapa kuesioner yang memodifikasi level dari keempat variabel independen, yaitu upah, kesempatan promosi, kebijakan PHK, dan kebijakan lingkungan. Setiap variabel memiliki level tinggi dan rendah. Dengan mengkombinasikan level keempat variabel tersebut secara tepat, skenario-skenario yang disajikan menciptakan semua kombinasi variabel yang mungkin terjadi dan dapat menilai bobot yang diberikan untuk setiap faktor oleh responden. Dengan empat variabel tersebut, dimana masing-masing variabel memiliki dua level (rendah dan tinggi), penelitian ini menggunakan disain $2 \times 2 \times 2 \times 2$ yang menghasilkan enam belas skenario untuk setiap variabel dependen. Enam belas skenario untuk variabel ketertarikan pada organisasi dan enam belas skenario untuk variabel intensi untuk mendapatkan pekerjaan, secara sekaligus diisi oleh responden yang sama. Sehingga, tidak ada perbedaan persepsi untuk kedua konsep variabel dependen.

\section{Instrumen Penelitian}

Kuesioner menggunakan skala likert 6 poin. Untuk memperjelas skenario yang diajukan kepada responden, berikut adalah template untuk variabel ketertarikan pada organisasi:

Jika saya adalah seorang fresh graduate dari Fakultas Ekonomi Universitas Indonesia, sementara suatu organisasi dengan kondisi sebagaimana berikut :

- Memberikan penawaran upah per bulan pada awal bekerja sebesar (Rp 2.200.000 / Rp 4.000.000) kepada karyawannya.

- Menjanjikan karyawannya untuk dipromosikan (nol / dua) kali dalam lima tahun.

- Memiliki kebijakan PHK dimana (karyawan dapat di-PHK kapan pun dengan alasan apa pun / tidak ada karyawan yang akan di-PHK, kecuali dalam kondisi yang sangat mendesak).

- Menerapkan kebijakan lingkungan dimana (organisasi menghasilkan produk/jasa yang tidak mempedulikan keselamatan lingkungan, menghasilkan polusi yang berlebih, dan tidak mengkomunikasikan komitmen untuk menjaga lingkungan kepada semua karyawannya / organisasi menghasilkan produk/jasa yang bersahabat dengan lingkungan (green product/service), melakukan pencegahan polusi yang berlebih, dan mengkomunikasikan komitmen untuk menjaga lingkungan kepada semua karyawannya).

\section{Metode Analisis Data}

Analisis Coding dan Input Data. Setiap variabel independen memiliki dua alternatif, antara 1 (ada/level tinggi) dan 0 (tidak ada/level rendah). Setiap skenario memiliki kombinasi empat variabel independen yang unik. Berdasarkan kalkulasi, maka untuk setiap responden akan diperoleh 16 kasus, masing-masing untuk ketertarikan pada organisasi dan intensi untuk mendapatkan pekerjaan. Oleh karena itu, dengan menggunakan 30 orang responden laki-laki dan 30 orang responden perempuan, akan diperoleh 960 kasus responden laki-laki dan 960 kasus responden perempuan.

Analisis Regresi Linear Berganda. Data akan dianalisis menggunakan metode regresi linear berganda dengan program SPSS. Metode ini dapat digunakan untuk melihat pengaruh sejumlah variabel independen (X1 s.d. $\mathrm{Xn}$ ) terhadap variabel dependen (Y). Selain itu juga digunakan untuk memprediksi nilai suatu variabel dependen (Y) berdasarkan nilai dari variabel-variabel independennya (X1 s.d. Xn).

Analisis Hubungan Moderasi. Untuk membuktikan efek moderasi jenis kelamin terhadap keempat independen variabel, maka data diolah terpisah antara respon dari subyek laki-laki dan perempuan. Dari kedua kelompok data tersebut diperoleh persamaan regresi yang berbeda. Dengan membandingkan konstanta dan koefisien variabel masing-masing persamaan, akan dapat diketahui ada tidaknya interaksi (interaction) dan efek moderasi (moderation effect) dari jenis kelamin terhadap keempat variabel independen. 
Dengan kata lain, penelitian ini juga ingin menganalisis apakah terdapat perbedaan faktor yang paling mempengaruhi ketertarikan pada organisasi dan intensi untuk mendapatkan pekerjaan antara kelompok berjenis kelamin laki-laki dan kelompok berjenis kelamin perempuan.

\section{HASIL DAN PEMBAHASAN}

Sebagaimana dituliskan pada Tabel 1, Koefisien untuk variabel upah, kesempatan promosi, kebijakan PHK, dan kebijakan lingkungan kesemuanya memiliki nilai signifikansi sebesar 0,000 (lebih kecil daripada a $=0,05$ ). Artinya, upah, kesempatan promosi, kebijakan PHK, dan kebijakan lingkungan kesemuanya memberikan pengaruh yang signifikan terhadap ketertarikan pada organisasi dan intensi untuk mendapatkan pekerjaan. Hasil ini juga menunjukkan bahwa kebijakan lingkungan memiliki pengaruh paling besar terhadap variabel ketertarikan pada organisasi, yaitu sebesar 0,411, diikuti oleh kesempatan promosi $(0,397)$, upah $(0,371)$, dan kebijakan PHK $(0,298)$. Sedangkan, upah memiliki pengaruh paling besar terhadap variabel intensi untuk mendapatkan pekerjaan, yaitu sebesar 0,418, diikuti oleh kesempatan promosi $(0,414)$, kebijakan PHK $(0,331)$, dan kebijakan lingkungan $(0,308)$.

\section{Tabel 1. Hasil Regresi}

Dari hasil yang telah diperoleh dari perhitungan regresi tersebut dapat membuktikan hipotesis penelitian 1,

\begin{tabular}{ccccc}
\hline Faktor & Ketertarikan pada & Organisasi & \multicolumn{2}{c}{ Intensi Mencari Pekerjaan } \\
& Signifikansi & Koefisien & Signifikansi & Koefisien \\
Upah & $\mathbf{0 , 0 0 0}$ & $\mathbf{0 , 3 7 1}$ & $\mathbf{0 , 0 0 0}$ & $\mathbf{0 , 4 1 8}$ \\
Promosi & $\mathbf{0 , 0 0 0}$ & $\mathbf{0 , 3 9 7}$ & $\mathbf{0 , 0 0 0}$ & $\mathbf{0 , 4 1 4}$ \\
K. PHK & $\mathbf{0 , 0 0 0}$ & $\mathbf{0 , 2 9 8}$ & $\mathbf{0 , 0 0 0}$ & $\mathbf{0 , 3 3 1}$ \\
K. Lingkungan & $\mathbf{0 , 0 0 0}$ & $\mathbf{0 , 4 1 1}$ & $\mathbf{0 , 0 0 0}$ & $\mathbf{0 , 3 0 8}$ \\
\hline
\end{tabular}

dimana kebijakan lingkungan yang dimiliki organisasi merupakan faktor yang paling kuat dalam mempengaruhi ketertarikan pada organisasi. Sedangkan hipotesis penelitian 2 tidak terbukti, karena faktor ke-dua yang paling kuat dalam mempengaruhi ketertarikan pada organisasi adalah kesempatan promosi, bukan kebijakan PHK yang dimiliki organisasi.

Jika dibandingkan dengan penelitian serupa (Aiman-Smith, Bauer, dan Cable, 2001), hasil penelitiannya memberikan output yang sama untuk faktor kebijakan lingkungan. Kebijakan lingkungan yang dimiliki organisasi menjadi faktor yang paling penting dalam mempengaruhi ketertarikan seseorang pada organisasi di dalam penelitian terdahulu ini. Namun demikian, terjadi perbedaan untuk urutan keduanya. Pada penelitian Aiman-Smith, Bauer, dan Cable (2001), hipotesis 2 dapat terbukti, dimana kebijakan PHK menjadi faktor terkuat ke-dua setelah kebijakan lingkungan. Namun hal ini tidak berlaku dalam ruang lingkup penelitian ini, khususnya untuk responden mahasiswa Fakultas Ekonomi Universitas Indonesia. Kesempatan promosi menjadi lebih penting dibandingkan kebijakan PHK ketika seseorang tertarik pada suatu organisasi.

Sikap ini menjadi gambaran bahwa mahasiswa tingkat akhir Fakultas Ekonomi Universitas Indonesia lebih mementingkan apa yang ditawarkan organisasi yang bersangkutan untuk perjalanan karir karyawannya, namun mengesampingkan faktor kebijakan PHK yang justru penting bagi organisasi untuk menjaga citra organisasi tersebut. Namun demikian, satu hal yang perlu digarisbawahi adalah, kebijakan-kebijakan yang bersifat sosial dan lingkungan tetap menjadi hal yang diperhatikan bagi responden dalam melihat citra organisasi dan pada akhirnya bisa tertarik pada organisasi tersebut. Hasil penelitian ini pun mendukung penelitian Judge dan Bretz (1992) yang menyatakan bahwa responden memberi peringkat tertinggi untuk dimensi lingkungan sebagai faktor yang mempengaruhi ketertarikan pada organisasi.

Untuk variable intensi untuk mendapatkan pekerjaan, hasil perhitungan regresi tersebut dapat membuktikan hipotesis penelitian 3, dimana tingkat upah yang ditawarkan organisasi merupakan faktor yang paling kuat dalam mempengaruhi intensi untuk mendapatkan pekerjaan. Selain itu, hipotesis 4 pun terbukti, dimana hasil perhitungan regresi menunjukkan bahwa kesempatan promosi yang ditawarkan organisasi merupakan faktor yang paling kuat setelah upah dalam mempengaruhi intensi untuk mendapatkan pekerjaan.

Jika dibandingkan dengan penelitian serupa (Aiman-Smith, Bauer, dan Cable, 2001), hasil penelitiannya memberikan output yang sama untuk variabel intensi untuk mendapatkan pekerjaan. Pada penelitian tersebut, tingkat upah yang ditawarkan organisasi menjadi faktor yang paling penting dalam mempengaruhi keinginan seseorang 
untuk bekerja pada sebuah organisasi. Sedangkan kesempatan promosi yang dijanjikan kepada karyawan juga menjadi urutan kedua yang mempengaruhi intensi untuk mendapatkan pekerjaan. Hasil penelitian ini pun sesuai dengan penelitian Feldman dan Arnold (1978), Rynes et al (1983), dan Strand et al (1981) yang menyatakan bahwa upah dan kesempatan promosi dikatakan sebagai atribut yang paling konsisten dari faktor pekerjaan yang mempengaruhi intensi untuk mendapatkan pekerjaan.

Hasil penelitian yang melibatkan responden di ruang lingkup Fakultas Ekonomi Universitas Indonesia ini juga ternyata paling mementingkan upah dan kesempatan promosi ketika mereka memutuskan ingin bekerja pada suatu organisasi. Hal ini merupakan sesuatu yang wajar karena seseorang yang ingin bekerja pada suatu organisasi tentunya mempertimbangkan imbalan yang sesuai dengan pekerjaannya. Jika upah yang diberikan dianggap tidak sesuai dengan beban kerja yang harus ditanggung, tentunya hal itu merupakan bentuk ketidakadilan dari sistem kompensasi suatu organisasi. Sedangkan untuk faktor promosi, hal ini penting untuk diperhitungkan sebelum mengambil keputusan bekerja. Promosi yang diberikan kepada karyawan tentunya menentukan perjalanan karir karyawan tersebut.

Penelitian ini juga menganalisis peran jenis kelamin sebagai variable moderasi. Sebagaimana yang ditunjukkan Tabel 2, ntuk memiliki ketertarikan pada suatu organisasi, kesempatan promosi menjadi faktor yang paling berpengaruh bagi kelompok responden berjenis kelamin laki-laki $(0,454)$, sedangkan kebijakan lingkungan menjadi faktor yang paling berpengaruh bagi kelompok responden berjenis kelamin perempuan $(0,492)$. Sedangkan, dalam hal keinginan bekerja pada suatu organisasi, kesempatan promosi menjadi faktor yang paling berpengaruh bagi kelompok responden berjenis kelamin laki-laki $(0,444)$, sedangkan upah menjadi faktor yang paling berpengaruh bagi kelompok responden berjenis kelamin perempuan $(0,410)$.

Tabel 2. Hasil rergresi dengan moderator jenis kelamin

\begin{tabular}{ccccc}
\hline Faktor & \multicolumn{2}{c}{$\begin{array}{c}\text { Ketertarikan pada Organisasi } \\
\text { (Koefisien) }\end{array}$} & \multicolumn{2}{c}{ Intensi Mencari Pekerjaan } \\
Upah & $\mathbf{L}$ & $\mathbf{P}$ & $\mathbf{L}$ & $\mathbf{P}$ \\
Promosi & 0,383 & 0,358 & 0,427 & 0,410 \\
K. PHK & 0,454 & 0,345 & 0,444 & 0,387 \\
K.Lingkungan & 0,296 & 0,300 & 0,356 & 0,309 \\
\hline
\end{tabular}

Dari hasil tersebut dapat ditarik kesimpulan bahwa ternyata faktor yang dianggap paling mempengaruhi ketertarikan pada organisasi maupun intensi untuk mendapatkan pekerjaan akan berbeda bagi laki-laki dan perempuan.

\section{PENUTUP}

\section{Kesimpulan dan Implikasi Manajerial}

Penelitian ini membuktikan bahwa upah, kesempatan promosi, kebijakan PHK, dan kebijakan lingkungan dari suatu organisasi memberikan pengaruh yang signifikan bagi calon karyawan potensial dalam memiliki ketertarikan pada organisasi dan juga intensi untuk mendapatkan pekerjaan di organisasi tersebut. Akan tetapi, ditemukan bahwa konsep ketertarikan pada organisasi dan intensi untuk mendapatkan pekerjaan merupakan dua konsep yang berbeda. Hal ini dibuktikan dengan adanya perbedaan factor-faktor yang mempengaruhi keduanya. Kebijakan lingkungan yang dimiliki organisasi merupakan faktor yang paling kuat dalam mempengaruhi ketertarikan pada organisasi, sedangkan factor ini berada di urutan terakhir sebagai pendorong untuk mencari pekerjaan di organisasi tersebut. Penelitian ini menemukan bahwa besaran upah lah yang merupakan factor terpenting bagi responden dalam mencari pekerjaan.

Temuan lebih menarik adalah adanya perbedaan laki-laki dan perempuan dalam kedua konsep ini. Untuk merasa tertarik pada suatu organisasi, kelompok berjenis kelamin laki-laki menganggap penting dan mempertimbangkan faktor kesempatan promosinya, sedangkan kelompok berjenis kelamin perempuan lebih melihat kebijakan lingkungan yang dimiliki organisasi tersebut. Hasil yang tidak terduga juga didapatkan untuk variable intensi untuk mendapatkan pekerjaan, dimananya ternyata perempuan lebih mementingkan factor upah 
dibandingkan laki-laki, yang lebih melihat factor kesempatan promosi.

Oleh karena itu, organisasi perlu menyusun paket kompensasi yang menarik bagi calon karyawan potensial Upah, yang menjadi faktor terkuat dalam mempengaruhi keinginan seseorang untuk bekerja di suatu organisasi/perusahaan tertentu, tentunya perlu dirancang sedemikian rupa agar kompetitif dengan organisasi/perusahaan lainnya. Sesuai dengan konsep remunerasi, kompensasi yang diberikan kepada karyawan haruslah memenuhi prinsip external equity (competitiveness), dimana kompensasi yang diberikan dirasa cukup bersaing oleh karyawan dengan apa yang diberikan oleh organisasi/perusahaan lain kepada karyawannya. Deng an demikian, organisasi/perusahaan tersebut memiliki competitive advantage dalam persaingan mendapatkan calon karyawan potensial yg terbaik. Organisasi juga perlu menyusun program rekruitmen yang tepat sasaran sesuai dengan apa yang diinginkan calon karyawan potensial. Konsep rekruitmen yang bisa menyampaikan keempat faktor tersebut dengan baik kepada calon karyawan potensial, tentunya akan meningkatkan minat mereka terhadap organisasi tersebut. Diharapkan dengan tingginya minat mereka, organisasi/perusahaan akan mendapatkan SDM yang berkualitas yang tentunya juga mengharapkan kondisi yang ideal di organisasi tersebut.

\section{DAFTAR PUSTAKA}

Aiman-Smith, L., Bauer, T. N., \& Cable, D. M. (2001). Are you attracted? Do you intend to pursue? A recruiting policy-capturing study. Journal of Business and Psychology, 16 (2), pp. 219-237.

Aiman-Smith, L., Scullen, S. E., \& Barr, S. H. (2002). Conducting studies of decision making in organizational contexts: A tutorial for policy-capturing and other regression-based techniques. Organizational Research Methods, 5 (4), pp. 388-414.

Anderson, E. (1992). Going Green: The corporate push for environmental consciousness. Business Credit, 94, 14-17.

Barber, A. (1998). Recruiting employees : Individual and organizational perspectives. Thousand Oaks, CA: Sage Publications.

Barclay, L. A., \& York, K. M. (2003). Clear logic and fuzzy guidance: A policy capturing study of merit raise decisions. Public Personnel Management, 32 (2), pp. 287.

Brooks, M.E., Highhouse, S., Russell, S., \& Mohr, D. (2003). Familiarity, Ambivalence, and Firm Reputation: Is Corporate Fame a Double-Edged Sword? Journal of Applied Psychology, 904-914.

Brown, T., \& Dacin, P. (1997). The company and the product: Corporate associations and consumer product services. Journal of Marketing, 61, 68-84.

Cable, D. M., \& Graham, M. E. (2000). The determinants of job seekers' reputation perceptions. Journal of Organizational Behavior, 21, 929-947.

Cable, D. M., \& Turban, D. B. (2001). Establishing the dimensions, sources and value of job seekers' employer knowledge during recruitment. In G. R. Ferris (Ed.), Research in personnel and human resources management (pp. 115-163). New York: Elsevie Science.

Cable, D., \& Judge, T. (1994). Pay preferences and job search decisions. A person-organization fit perspective. Personnel Psychology, 47, 317-348.

Carlson, L., Grove, S., \& Kangun, N. (1993). A content analysis of environmental advertising claims : A method matrix approach. Journal of Advertising, 22, 27-39

Chatman, J. A. (1989). Improving interactional organizational research: A model of person-organization fit. Academy of Management Review, 14, 333-349.

Cooper, D. R., \& Schindler, P. S. (2006). Business Research Method. New York: Mc Graw Hill.

Deshpande, S. P., \& Schoderbek, P. P. (1993). Pay-allocations by managers: A policy-capturing approach. Human Relations. 46 (4), pp. 465-479.

Doeringer, P.B., \& Piore, M. (1971). Internal labor markets and manpower analysis. Lexington, MA.: Lexington Books, Inc.

Dowling, G. (1986). Managing your corporate image. Industrial Marketing Management, 15, 109-115

Feldman, D., \& Arnold, H. (1978). Position choice: Comparing the importance of organizational and job factors. Jounal of Applied psychology, 63, 706-710.

Fishbein, M., \& Ajzen, I. (1975). Belief. attitude. intention and behavior: An introduction to theory and research. Reading, MA.: Addison-Wesley. 
Gatewood, R. D., Gowan, M. A., \& Lautenschlager, G. J. (1993). Corporate image, recruitment image, and initial job choice decisions. Academy of Management Journal, 36, 414-427.

Gerhart, B., \& Milkovich, G. T. (1990). Organizational differences in managerial compensation and financial performance. Academy of Management Journal, 8,663-691.

Gomez-Mejia, L. R., \& Balkin, D. B. (1992). Compensation, organizational strategy, and firm performance. Cincinnati, OH: South-Western Publishing Co.

Gregory, J. (1991). Marketing corporate image : The company as your \#1 product. Lincoln-wood, IL : NTC Business Books.

Hasibuan, M. (2001). Manajemen Sumber Daya Manusia. Jakarta: PT. Bumi Aksara

Hasibuan, M. (2002). Manajemen Sumber Daya Manusia. (Edisi Revisi). Jakarta: PT. Bumi Aksara

Hobson, C. J., \& Gibson, F. W. (1983). Policy capturing as an approach to understanding and improving performance appraisal: A review of literature. Academy of Management. The Academy of Management Review, 8 (4), pp. 640-649.

Honeycutt, T. L., \& Rosen, B. (1997). Family friendly human resource policies, salary levels and salient identity as predictors of organizational attraction. Journal of Vocational Behavior, 50, 271-290.

Hu, H. H., Hsu, C. T., Lee, W. R., \& Chu, C. M. (2007). A policy-capturing approach to comparing the reward allocation decisions of Taiwanese and US managers. Social Behavior and Personality, 35 (9), pp. 12351250 .

ISO 14001

ISO 26000

Judge, T., \& Bretz, R. (1992). Effects of work values on job choice decisions. Journal of Applied Psychology, 77, 261-271.

Jurgensen, C. E. (1978). Job preferences (What makes a job good or bad?.) Journal of Applied Psychology, 63, 267-276.

Kerr, C., \& Fisher, L.H. (1950). Effect of environment and administration on job evaluation. Harvard Business Review, 77-96.

Kinder, S., Lydenberg, S., \& Domini, A. (1992). The social investment almanac. New York: H. Holt and Co.

Lakhani, H. (1988). The effect of pay and retention bonuses on quit rates in the U.S. Anny. Industrial and Labor Relations Review, 41, 430-438.

Lâmsâ \& Savolainen. (2000). The impact of downsizing on trust and employee practices in high tech firms: A longitudinal analysis

Law, K. S. \& Wong, C. S. (1998). Relative importance of referents on pay satisfaction: A review and test of a new policy-capturing approach. Journal of Occupational and Organizational Psychology, 71, pp. 47-60.

Lievens, F., \& Highhouse, S. (2003). The relation of instrumental and symbolic attributes to a company's attractiveness as an employer. Personnel Psychology, 56, 75-102.

Lievens, F., Decaesteker, C., Coetsier, P., \& Geirnaert, J. (2001). Organizational attractiveness for prospective applicants: A person-organization fit perspective. Applied Psychology: An International Review, 50, $30-51$.

Lowry, R. (1991). Good money : A guide to profitable social investing. New York : W. W. Norton.

Malhotra, N. K. (2004). Marketing Research. New Jersey : Pearson International.

Malm, F. T. (1955). Hiring procedures and selection standards in the San Francisco Bay area. Industrial and Labor Relations Review, 8, 231-252.

Manullang. (2000). Manajemen Personalia.

Milkovich, George T., \& Newman, Jerry M. (2008). Compensation. ( ${ }^{\text {th }}$ ed). New York: Mc Graw Hill.

Miller, A. (1991). Social responsible investing. New York : New York Institute of Finance.

Millstone, M., \& Watts, F. H. (1992). Effect of the green movement on business. Indonesia

Nitisemito, Alex S. (1996). Manajemen Personalia : Manajemen Sumber Daya Manusia. Jakarta : Ghalia

Nitisemito, Alex S. (2001). Manajemen Personalia. Jakarta: Ghalia Indonesia

Noe, Raymond A. (2005). Employee Training and Development. New York: Mc Graw Hill. 
Norman, L. (1977) Human Information Processin. ( ${ }^{\text {nd }}$ Ed). San Diego, CA: Harcourt Brace Jovanovich.

Ottman, J. (1992). Green marketing. Lincolnwood, IL : NTC Business Books.

103-111

Peattie, K., \& Ratnayaka, M. (1992). Building the green movement. Industrial Marketing Management, 21,

Pfeffer, J. (1998). The human equation : Building profits by putting people first. Boston: Harvard Business School Press.

Powell, G.N., \& Goulet, L.R. (1996). Recruiters' and applicants' reactions to campus interviews and employment decisions. Academy of Management Journal, 39, 6, 1619-1640.

Ravlin, E.C., \& Meglino, B.M. (1987). Effects of values on perception and decision making: A study of alternative work values measures. Journal of Applied Psychology, 72, 666-673.

Rynes, S. (1991). Recruitment, job choice, and post-hire consequences : A call for new research directions. Handbook of industrial and organizational psychology. $\left(2^{\text {nd }}\right.$ ed). Palo Alto, CA: Consulting Psychologists Press.

Rynes, S. L., Heneman, H. G., \& Schwab, D. P. (1980). Individual reactions to organizational recruiting: A review. Personnel Psychology, 33, 529-542.

Rynes, S., \& Barber, A. (1990). Applicant attraction strategies : An organizational persperctive. Academy of Management Review, 15, 286-310

Rynes, S., \& Lawyer, J. (1983). A policy-capturing investigation of the role of expectancies in decision to pursue job alternatives. Journal of Applied Psychology, 68, 620-681.

Rynes, S., Schwab, D., \& Heneman, H. (1983). The role of pay and market pay variability in job application decisions. Organizational Behavior and Human Performance, 31, 353-364.

Schneider, B. (1987). The people make the place. Personnel Psychology, 40, 437-453.

Schneider, J., \& Levine, E. (1987). Determining important tasks within jobs : A policy-capturing approach. Journal of Applied Psychology, 74, 336-342.

Schwab, D. P., Rynes, S. L., \& Aldag, R. J. (1987). Theories and research on job search and choice. In Rowland KM, Ferris GR (Eds.), Research in personnel and human resource management (Vol. 5, pp. 126-166). Greenwich, CT: JAI Press

Slaughter, J. E., Richard, E. M. \& Martin, J. H. (2006). Comparing the efficacy of policy-capturing weights and direct estimates for predicting job choice. Organizational Research Methods, 9 (3), pp. 285-314.

Survey Gaji Indonesia Tahun 2007. Majalah SWA. (Februari 2007). Edisi 15-28.

Thurow, L. (1975). Generating inequality. New York: Basic Books.

Turban, D. B. (2001). Organizational attractiveness as an employer on college campuses: An examination of the applicant population. Journal of Vocational Behavior, 58, 293-312.

Turban, D. B., \& Greening, D. W. (1997). Corporate social performance and organizational attractiveness to prospective employees. Academy of Management Journal, 40, 658-672.

Turban, D. B., \& Keon, T. L. (1993). Organizational attractiveness: An interactionist perspective. Journal of Applied Psychology, 78, 184-193.

Turban, D. B., Forret, M. L., \& Hendrickson, C. L. (1993). Influences of organization reputation, job attributes, and recruiter behaviors on applicant attraction to firms: A comparison of structural models.

UU No. 13 Tahun 2003

Waski, J. (1992). Green marketing and management : A global perspective. Cambridge, MA : Blackwell Business.

Wiederman, M. W. (1999). Policy capturing methodology in sexuality research. The Journal of Sex Research, 36 (1), pp. 91-95.

Williamson, C. L, Cope, J. G., Thompson, L. F. \& Wuensch, K. L. (2002). Policy capturing as a tool to enhance recruiting. Career Development International, 7 (3), pp. 159-166.

Yellen, J. L. (1984). Efficiency wage models of unemployment. American Economic Review, 74, 200-205.

Zedeck, S. (1977). An information processing model and approach to the study of motivation. Organizational Behavior and Human Performance, 18, 47-77.

Zhou, J., \& Martocchio, J. J. (2001). Chinese and American managers' compensation award decisions: A comparative policy-capturing study. Personnel Psychology, 54 (1), pp. 115-145. 